\title{
Essential Oils Obtained from Aerial Eugenia punicifolia Parts: Chemical Composition and Antiproliferative Potential Evidenced through Cell Cycle Arrest
}

\author{
Yan M. L. Fernandes, ${ }^{a}$ Julia V. S. Matos, ${ }^{\circledR b}$ Carolina A. Lima, ${ }^{b}$ Angela M. Tardini, ${ }^{b}$ \\ Flavio A. P. Viera, ${ }^{a}$ Jose G. S. Maia, ${ }^{\circledR a}$ Odair S. Monteiro, ${ }^{a}$ Giovanna B. Longato ${ }^{b}$ and \\ Cláudia Q. Rocha ${ }^{\circledR * a}$
}

${ }^{a}$ Laboratório de Química de Produtos Naturais, Departamento de Química, Universidade Federal do Maranhão, 65080-805 São Luís-MA, Brazil

${ }^{b}$ Laboratório de Pesquisa em Farmacologia Molecular e Compostos Bioativos, Universidade São Francisco, 12916-900 Bragança Paulista-SP, Brazil

\begin{abstract}
Essential oils (EOs) of the leaves of three Eugenia punicifolia specimens from two different Reservation Parks, namely Parque Nacional das Nascentes do Rio Parnaíba (EpNRP-I and EpNRP-II) and Parque Nacional da Chapada das Mesas (EpCM), in the state of Maranhão, Brazil, were extracted by hydrodistillation and investigated by gas chromatography coupled to mass spectrometry. Principal component and hierarchical cluster analyses indicated differences between the samples. Antiproliferative EOs activity was determined for U-251 (glioblastoma), MCF-7 (breast adenocarcinoma), NCI/ADR-RES (multidrug-resistant ovarian adenocarcinoma), OVCAR-3 (ovarian adenocarcinoma), HT-29 (colorectal adenocarcinoma), and HaCaT (non-tumor keratinocyte) cell lines applying the colorimetric method using 3-(4,5-dimethyl2-thiazolyl)-2,5-diphenyl-2H-tetrazolium bromide (MTT) to determine the $\mathrm{GI}_{50}(50 \%$ growth inhibition) concentration. The extraction yields of the analyzed EOs were $0.58,1.42$ and $0.84 \%$. The main constituents identified in two samples were $\alpha$-pinene $(49.75 \%), 1,8$-cineole $(13.77 \%)$ and $\alpha$-terpineol $(7.32 \%)$, and in the third sample, germacrene B $(16.25 \%),(E)$-caryophyllene $(13.21 \%)$ and $\beta$-pinene $(12.81 \%)$. The main $\mathrm{GI}_{50}$ results for sample EpNRP-I were noted for the U-251 $\left(2.13 \mu \mathrm{g} \mathrm{mL}^{-1}\right)$ and MCF-7 $\left(6.72 \mu \mathrm{g} \mathrm{mL}^{-1}\right)$ tumor lines. For the non-tumoral line HaCaT, the calculated $\mathrm{GI}_{50}$ was higher than the positive control comprising doxorubicin hydrochloride $\left(13.35 \mu \mathrm{g} \mathrm{mL}^{-1}\right)$. In addition, a flow cytometry analysis revealed that this same sample arrests the cell cycle of the MCF-7 line in the second interphase stage.
\end{abstract}

Keywords: Myrtaceae, cerrado, monoterpenes, sesquiterpenes, chemotypes, cytotoxicity

\section{Introduction}

Myrtaceae has more than 5600 species distributed between 130 to 140 genera. ${ }^{1,2}$ It is native to the Cerrado and other biomes in the tropical and subtropical areas of South America, Australia, and Asia. In Brazil, it is considered one of the ten richest families of angiosperms and also one of the ten most expressive in the Cerrado region, where at least 14 of the 23 genera occurring in the country could be found. ${ }^{1,3}$ It is also known for producing high content of terpenes, the main constituents of its

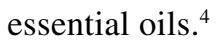

Several research groups seek to study in a non-predatory way the potential of Brazilian biodiversity, in particular,

*e-mail: claudiarocha3@yahoo.com.br the aromatic flora and its essential oils from the North and Northeast of Brazil. Studies are being carried out and adding knowledge about this rich flora, either to develop new technologies from natural products or to learn about the phytochemical characteristics of these species. This work is part of the effort that a group of researchers from federal universities in the North and Northeast of Brazil has been making, whose main objective is to investigate the potential of aromatic plants in the Amazon biome.

A database that lists several aromatic species collected in the nine states of the Brazilian Amazon has been published, ${ }^{5}$ confirming not only the richness of the Amazonian flora but also its phytochemical potential. This study has been underway for more than 30 years, which reflects a significant example of how much remains to be discovered in the Brazilian biodiversity. The Cerrado biome 
in Brazil has been rapidly deforested, with about $2.2 \%$ of its area each year. Before, it represented about 2 million $\mathrm{km}^{2}$, almost a quarter of the total area of the country. Today, less than $1.0 \%$ of its original area is part of protected reserves in Brazil. Despite this, Cerrado is still responsible for about $12.0 \%$ of the known plant species. ${ }^{6}$

Eugenia L., belonging to the Myrtaceae family, presents approximately 1000 species, with occurrence in Central and South America, and few in the African continent. They are shrubs or small trees with twigs glabrous or pubescent when young. ${ }^{7}$

Essential oils (EOs) obtained from Eugenia species are noteworthy for displaying significant economic and pharmacological potential, such as cytotoxic, ${ }^{1}$ antibacterial, ${ }^{8}$ antifungal, ${ }^{9}$ and insecticide activities. ${ }^{10}$ The compounds present in the EOs of this genus, such as the monoterpenes $\alpha$ and $\beta$-pinene, limonene, and $\gamma$-terpinene, the sesquiterpenes germacrene $\mathrm{B}, \alpha$-humulene, and $(E)$-caryophyllene, as well the phenylpropanoid eugenol, have been described as displaying cytotoxic, and anticancer activities. , $, 5,11,12^{2}$

The antiproliferative activity of the EOs of nine Eugenia species has recently been described ${ }^{13}$ highlighting promising results for E. cuspidifolia and E. tapacumensis in inhibiting cell migration and cell proliferation of HCT-116 colorectal cell line colonies. In addition, the EOs are not genotoxic and, therefore, do not cause DNA damage.

Based on the studies reported ${ }^{2,3,14}$ for the Eugenia genus, it was observed that some common constituents existing in the genus essential oils have already shown antineoplastic activities, either isolated or in synergy with each other. One Eugenia species that has been the focus on work by our group is Eugenia punicifolia (Kunth) DC. (syn. E. ambigua O.Berg, E. benthamii O.Berg, E. fruticulosa DC., E. insipida Cambess., E. sancta DC., Myrtus punicifolia Kunth, among many others). This is an endemic species with a wide distribution in Brazil, occurring in the biomes of the Amazon and Atlantic Forest and the Cerrado and Caatinga of the Northeast. It is a shrub of up to $3 \mathrm{~m}$ and known as "cereja-da-praia", "cereja-do-campo", "murta", "pitanga-do-campo", and others with antinociceptive, anti-inflammatory and antibacterial properties described in literature, ${ }^{12,15,16}$ but no one related to anticancer activity.

Therefore, studies on the chemical composition of EOs obtained from the aerial parts of E. punicifolia, allied to antiproliferative screening, may contribute to phytochemical and biological knowledge on Eugenia species. In this context, the aims of the present study are to evaluate the chemical composition and the potential technological application of Eugenia punicifolia EOs, aiming at the promising use of their chemical and biological properties in favor of the Brazilian society.

\section{Experimental}

\section{Plant material}

Aerial parts of Eugenia punicifolia were collected at Alto do Rio Parnaíba, Parque Nacional Nascentes do Rio Parnaíba, Maranhão State, Brazil, samples EpNRP-I (coordinates 09 $10^{\prime} 34.7^{\prime \prime} \mathrm{S}, 4^{\circ} 55^{\prime} 57.8^{\prime \prime} \mathrm{W}$ ) and EpNRP-II (coordinates 09 ${ }^{\circ} 13^{\prime} 07.1^{\prime \prime} \mathrm{S}, 45^{\circ} 54^{\prime} 15.9^{\prime}$ ' W), May 2014; and at Carolina City, Parque Nacional Chapada das Mesas, Maranhão State, Brazil, sample EpCM (coordinates $07^{\circ} 07^{\prime} 47.1$ ' S, 4²5'36.8” W). The plant vouchers were identified in the Herbarium of Emílio Goeldi Museum, Belém City, PA, Brazil, and compared with an authentic sample, under the number MG 181810. The leaves were dried at room temperature for 5 days, ground, and then stored to further processing. The plant was collected in agreement with the Brazilian laws concerning the protection of biodiversity (SisGen No. AD7DF67).

\section{Essential oil extraction and yield calculation}

Leaf samples $(50 \mathrm{~g})$ were submitted to hydrodistillation using a Clevenger-type apparatus (3 h) (LaborQuimi, São Paulo, Brazil).,5 The oils were dried over anhydrous sodium sulfate (Merck-Millipore, São Paulo, Brazil), and the percentage contents were calculated on basis of the dry weight of plant material. The moisture content of the samples was calculated using an Infrared Moisture Balance (Genaka, São Paulo, Brazil) for water loss measurement. The procedure of the moisture content was performed in duplicate.

\section{Oil-composition analysis}

The analysis of the EO samples was performed on a gas chromatograph coupled to mass spectrometer (GCMS)-QP2010 Ultra system (Shimadzu Corporation, Tokyo, Japan), equipped with the GCMS-Solution software containing the NIST $11,{ }^{17}$ FFNSC $2,{ }^{14}$ and Adams ${ }^{18}$ libraries. An Rxi-5ms ( $30 \mathrm{~m} \times 0.25 \mathrm{~mm}$; $0.25 \mu \mathrm{m}$ film thickness) silica capillary column (Restek Corporation, Bellefonte, PA, USA) was used. The conditions of analysis were: injector temperature of $250{ }^{\circ} \mathrm{C}$; oven temperature programming of $60-240{ }^{\circ} \mathrm{C}\left(3^{\circ} \mathrm{C} \mathrm{min}^{-1}\right)$; the helium as carrier gas, adjusted to a linear velocity of $36.5 \mathrm{~cm} \mathrm{~s}^{-1}\left(1.0 \mathrm{~mL} \mathrm{~min}^{-1}\right)$; split mode injection for $1.0 \mu \mathrm{L}$ of the sample (oil $3.0 \mu \mathrm{L}$ :hexane $500 \mu \mathrm{L}$ ); split ratio 1:20; ionization by electronic impact at $70 \mathrm{eV}$; ionization source and transfer line temperatures of 200 and $250{ }^{\circ} \mathrm{C}$, respectively. The mass spectra were 
obtained by automatic scanning every $0.3 \mathrm{~s}$, with mass fragments in the range of $\mathrm{m} / \mathrm{z} 35-400$. The retention index was calculated for all volatile components using a homologous series of C8-C40 n-alkanes (Sigma-Aldrich, Saint Louis, USA), according to the linear equation of Van Den Dool and Kratz. ${ }^{19}$ The quantitative data regarding the volatile constituents were obtained using a GC 2010 series, coupled to flame ionization detector (FID), operated under similar conditions of the GC-MS system. The components were identified by comparing their retention indexes and mass spectra (molecular mass and fragmentation pattern) with those existing in the GCMS-solution system libraries.

\section{Antiproliferative activity assay}

The colorimetric assay 3-(4,5-dimethyl-2-thiazolyl)2,5-diphenyl-2 $H$-tetrazolium bromide (MTT), SigmaAldrich, St. Louis, Missouri, USA), which indirectly evaluates cell viability through the activity of mitochondrial reductase enzyme, ${ }^{20}$ was used to evaluate cell proliferation as described by Franco et al. ${ }^{21}$ Briefly, 5 tumor cell lines: U-251 (glioblastoma), MCF-7 (adenocarcinoma), NCI/ ADR-RES (multi-drug resistant ovarian adenocarcinoma), PC-3 (prostate adenocarcinoma), OVCAR-3 (ovarian adenocarcinoma), HT-29 (colorectal adenocarcinoma) and one non-tumoral cell line HaCaT (keratinocyte), were seeded into 96-well plates $\left(5 \times 10^{3}\right.$ cells well $\left.^{-1}\right)$ and allowed to grow overnight to adhere. The EO samples were dissolved in dimethyl sulfoxide (DMSO, Merck, Darmstadt, Germany) and diluted with Roswell Park Memorial Institute (RPMI) medium to final concentrations ranging from 1.6 to $100 \mu \mathrm{g} \mathrm{mL} \mathrm{m}^{-1}$. The final concentration of DMSO in the culture medium was kept constant, below $0.1 \%$ (v/v). A control plate (T0 plate) was used to detect the basal number of cells. As a positive control, doxorubicin was used at the same concentrations. After $48 \mathrm{~h}, 100 \mu \mathrm{L}$ MTT reagent $\left(0.25 \mathrm{mg} \mathrm{mL}^{-1}\right.$ per well) was added followed by incubation for $4 \mathrm{~h}$ at $37{ }^{\circ} \mathrm{C}$. The absorbance (value) at $470 \mathrm{~nm}$ wavelength was measured using a microplate reader (Epoch BIOTEK ${ }^{\circledR}$, Winooski, Vermont, USA). The $\mathrm{GI}_{50}$ (concentration required to inhibit $50 \%$ cell growth) values were determined by nonlinear regression analysis using software Origin 8.0.22 The selectivity index (SI) was also calculated. SI is an analysis that allows measuring how more selective the compound is to tumor cells than non-tumor cells. This analysis can be obtained by dividing the $\mathrm{GI}_{50}$ value of a non-tumor cell line by a tumor cell line. In this assay, the SI was calculated by the following equation 1 :

$\mathrm{SI}=\frac{\mathrm{GI}_{50} \mathrm{HaCaT}}{\mathrm{GI}_{50} \text { tumor cell lines }}$
MCF-7 was the cell line chosen to continue the studies, according to the sensitivity of the sample on the antiproliferative activity assay.

\section{Soft agar clonogenic assay}

A mix containing MCF-7 cells $\left(1 \times 10^{5}\right)$ agar, and RPMI medium supplemented twice with $20 \%$ of FBS (fetal bovine serum) $+1 \% \mathrm{P} / \mathrm{S}$ (penicillin/streptomycin) per well was seeded in a 6-well plate and incubated at $37{ }^{\circ} \mathrm{C}$ in a $5 \% \mathrm{CO}_{2}$ incubator. Every three days the samples were treated with DMSO (1\%) and EpNRP-I $\left(7 \mu \mathrm{g} \mathrm{mL} \mathrm{m}^{-1}\right)$. After 21 days in culture, the medium was removed, the wells were washed with distilled water and the colonies were then fixed with formaldehyde (4\%) and stained with crystal violet $(0.005 \%)$. The wells were photographed, and the images analyzed in the ImageJ software, ${ }^{23}$ for quantification of the colonies.

\section{Cell cycle analysis}

This experiment was done using Guava ${ }^{\circledR}$ Cell Cycle reagent (Austin, TX, USA), as previously described. ${ }^{24}$ Briefly, MCF-7 cells $\left(5 \times 10^{4}\right.$ cells well $\left.^{-1}\right)$ in 12-well plates with the complete medium were incubated at $37{ }^{\circ} \mathrm{C}$ with $5 \% \mathrm{CO}_{2}$ for $24 \mathrm{~h}$. Then, the complete medium was replaced by RPMI medium without fetal bovine serum (FBS) for cell cycle synchronization and cells were incubated for another $24 \mathrm{~h}$. After that, the cells were treated with DMSO (negative control), etoposide (positive control, $5.89 \mu \mathrm{g} \mathrm{mL}^{-1}$ or $10 \mathrm{mM})$ and EpNRP-I $\left(7 \mu \mathrm{g} \mathrm{mL} \mathrm{m}^{-1}\right)$ during $24 \mathrm{~h}$. The cells were harvested, collected, centrifuged (5 min, $2500 \mathrm{rpm}$ ), and the supernatant discarded. After fixation with $70 \%$ cold ethanol $\left(24 \mathrm{~h}, 4{ }^{\circ} \mathrm{C}\right)$, each cell suspension was centrifuged and washed with phosphate-buffered saline (PBS), the supernatant was discarded, and then the Guava Cell Cycle reagent ( $200 \mu \mathrm{L} \mathrm{cell}^{-1}$ suspension) was added. After $20 \mathrm{~min}$ at room temperature in the dark, each cell suspension was analyzed (5000 events per replicate) by flow cytometry. Using the Guava Cell cycle ${ }^{\circledR}$ software, ${ }^{25}$ the subpopulations at $\mathrm{G} 1, \mathrm{~S}$, and $\mathrm{G} 2 / \mathrm{M}$ phases of the cell cycle were quantified in percentage. The analyses were done in biological triplicate of two experiments.

\section{Statistical analysis}

Results were expressed as mean \pm standard deviation (SD) of three independent experiments conducted in duplicate. Statistical analyses were performed with the GraphPad Prism 5 software. ${ }^{26} t$-Test and analysis of variance (ANOVA) followed by Bonferroni post hoc test 
were used, and $p$-values less than 0.05 were considered significant. For the cytotoxic activity assay, the linear regression of the curves was obtained using the mean growth percentage and, calculated with Origin ${ }^{\circledR}$ software. ${ }^{22}$ The oils components with a percentage higher than $1 \%$ of the total oil were subjected to hierarchical cluster analysis (HCA) and principal component analysis (PCA) using SPSS v22.0 software. ${ }^{27}$ In the case of HCA, the dendrogram was produced using Ward's method of hierarchical clustering with squared Euclidean distance between oil samples.

\section{Results and Discussion}

\section{Yield and oil-composition}

The oil yields of EpNRP-I, EpNRP-II, and EpCM from E. punicifolia leaves were $1.4,0.8$, and $0.6 \%$, respectively. The percentage content of oil sample EpNRP-I was higher than those previously reported. ${ }^{28}$ The EpNRP-I and EpNRP-II oils showed a monoterpenoids profile predominantly (above 5\%), with $\alpha$-pinene (49.8 and 53.6\%), 1,8-cineole (13.8 and 11.7\%), $\alpha$-terpineol (7.3 and $7.6 \%$ ), and limonene (5.1 and 5.0\%) as the primary constituents. On the other hand, the EpCM oil consisted of monoterpenoids and sesquiterpenoids, where germacrene $\mathrm{B}$ (16.3\%), (E)-caryophyllene (13.2\%), $\beta$-pinene (12.8\%), (E)- $\beta$-ocimene $(12.4 \%)$, bicyclogermacrene $(7.0 \%)$, germacrene $\mathrm{D}(5.3 \%)$, and $\alpha$-pinene $(5.2 \%)$ were its main compounds. Thus, monoterpene hydrocarbons $(\mathrm{MH})$ and oxygenated monoterpenes (OM) predominated in the oils of EpNRP-I (MH 57.6\%; OM 24.2\%) and EpNRP-II (MH 61.3\%; OM 24.9\%), while the sesquiterpene hydrocarbons $(\mathrm{SH})$ and $\mathrm{MH}$ occurred preferably in the oil of EpCM (SH 53.2\%; MH 32.6\%), as can be seen in Table 1. Considering that the collection sites of the EpNRP-I and EpNRP-II, and EpCM samples were different, as well as the composition of their essential oils, one can assume in this work the occurrence of two distinct chemotypes to E. punicifolia existing in the Cerrado areas of Maranhão, Brazil.

It is important to take into account that geographic and environmental factors influence plant growth in different locations, while soil water and nutrient availability, sunlight, circadian and seasonal effects, and herbivory, among others, may alter EO composition. ${ }^{29}$

The EpNRP-I and EpNRP-II oils samples showed chemical characteristics quite different from the EpCM sample. However, most primary mono- and sesquiterpenes constituents of the oils from E. punicifolia were the same, as $\alpha$-pinene, germacrene $\mathrm{B}, 1,8$-cineole, $(E)$-caryophyllene, $\beta$-pinene, $(E)$ - $\beta$-ocimene, $\alpha$-terpineol, bicyclogermacrene, limonene, and germacrene $\mathrm{D}$, all of them arranged by their biosynthetic pathways and in an increasing elution order as can be seen in Table 1, and with the chemical structures displayed in Figure 1. In the mevalonate pathway, acyclic monoterpenes, such as $(E)$ - $\beta$-ocimene, result from the conversion of geraniol or linalool, leading to the other monoterpene constituents identified in E. punicifolia oils. ${ }^{30}$ $(E)$ - $\beta$-Ocimene was found only in EpCM oil, suggesting that the plant sampled in Chapada das Mesas was younger than the samples of EpNRP-I and EpNRP-II plants collected in the Rio Parnaíba region, since it is a precursor molecule in the biosynthesis of other monoterpenes identified in the oils of E. punicifolia.

The oils of two E. punicifolia specimens collected at Manaus-Caracaraí Road and Manaus-ltacoatiara Road, Amazonas State, Brazil, displayed three sesquiterpene hydrocarbons, $(E)$-caryophyllene, $\alpha$-humulene, and $\delta$-cadinene, as primary constituents. ${ }^{31}$ In the oils of E. punicifolia sampled at the localities of Serra Negra and Madre de Deus, Pernambuco State, Brazil, predominated linalool, $(E)$-caryophyllene and $\alpha$-terpineol. ${ }^{28}$ Also, the oil of an E. punicifolia specimen that is growing wild in sandbanks of Maracanã municipality, Pará State, Brazil, showed $(E)$-caryophyllene, bicyclogermacrene, germacrene $\mathrm{D}$, and $(E)$ - $\beta$-ocimene as the main volatile components. ${ }^{28}$ Additionally, the oil of another E. punicifolia specimen occurring at Restinga area of Macaé City, Rio de Janeiro, Brazil, presented $\alpha$-cadinol, 10-epi-eudesmol, paradisiol, 7-epi- $\alpha$-selinene, $(E)$-caryophyllene, and $\beta$-selinene as major compounds. ${ }^{32}$

The application of an HCA resulted in the dendrogram presented in Figure 2a, which indicates the composition of elements representing similarities between EpNRP-1 and EpNRP-1, while indicating that the EpCM sample was different from both. The PCA main components (PC1 and PC2) accounted for $100 \%$ of the total data variability, where PC1 explained $82.87 \%$ and component PC2, 17.13\% (Figure 2b). Regarding the EpNRP-I and II samples, the monoterpene hydrocarbon $\alpha$-pinene was the major constituent, present at approximately $50 \%$ of both samples. The EpCM sample, on the other hand, presented the sesquiterpene hydrocarbon germacrene $\mathrm{B}$ as the constituent present at the highest concentration in the EO, at approximately $16 \%$. These data explain the PCA and HCA results.

\section{Antiproliferative activity of EOs samples}

The EpNRP-II oil sample was not subjected to the antiproliferative analysis, due to a very similar volatile composition when compared to EpNRP-I and reduced availability. $\alpha$-Pinene, the monoterpene hydrocarbon 
Table 1. Yield and composition of Eugenia punicifolia oil samples

\begin{tabular}{|c|c|c|c|c|c|}
\hline Oil yield / \% & & & 1.4 & 0.8 & 0.6 \\
\hline Oil constituent / \% & $\mathrm{RI}_{\mathrm{C}}$ & $\mathrm{RI}_{\mathrm{L}}$ & EpNRP-I & EpNRP-II & EpCM \\
\hline Hexanal & 803 & 801 & - & 0.7 & - \\
\hline$\alpha$-Pinene & 935 & 932 & 49.8 & 53.6 & 5.2 \\
\hline$\alpha$-Fenchene & 946 & 945 & 0.1 & 0.3 & - \\
\hline Camphene & 948 & 946 & 0.6 & 1.6 & - \\
\hline$\beta$-Pinene & 978 & 974 & 1.6 & 0.3 & 12.8 \\
\hline Myrcene & 993 & 988 & - & - & 0.4 \\
\hline$p$-Cymene & 1025 & 1020 & 0.4 & 0.5 & - \\
\hline Limonene & 1029 & 1024 & 5.1 & 5.0 & 1.2 \\
\hline 1,8-Cineole & 1032 & 1026 & 13.8 & 11.7 & - \\
\hline (Z)- $\beta$-Ocimene & 1037 & 1032 & - & - & 0.6 \\
\hline$(E)-\beta$-Ocimene & 1047 & 1044 & - & - & 12.4 \\
\hline endo-Fenchol & 1117 & 1114 & 0.8 & 1.5 & - \\
\hline Borneol & 1169 & 1165 & 2.3 & 4.1 & - \\
\hline$\alpha$-Terpineol & 1193 & 1186 & 7.3 & 7.6 & - \\
\hline trans-Pinocarvyl acetate & 1304 & 1298 & - & - & 0.1 \\
\hline$\delta$-Elemene & 1338 & 1335 & - & - & 0.8 \\
\hline$\alpha$-Ylangene & 1376 & 1373 & 0.5 & - & - \\
\hline$\beta$-Elemene & 1393 & 1389 & - & - & 4.3 \\
\hline (E)-Caryophyllene & 1420 & 1417 & 4.3 & 3.2 & 13.2 \\
\hline$\beta$-Copaene & 1430 & 1430 & - & - & 0.2 \\
\hline$\gamma$-Elemene & 1434 & 1434 & - & - & 3.3 \\
\hline$\alpha$-Humulene & 1454 & 1452 & 0.6 & - & 1.3 \\
\hline 4,5-di-epi-Aristochene & 1470 & 1471 & 2.3 & 0.8 & - \\
\hline Germacrene D & 1482 & 1484 & - & - & 5.3 \\
\hline$\beta$-Selinene & 1487 & 1489 & 1.0 & - & - \\
\hline cis- $\beta$-Guaiene & 1490 & 1492 & 2.0 & - & - \\
\hline Bicyclogermacrene & 1497 & 1500 & - & - & 7.0 \\
\hline 7-epi- $\alpha$-Selinene & 1519 & 1520 & 0.5 & - & - \\
\hline$\delta$-Cadinene & 1525 & 1522 & - & - & 1.5 \\
\hline Germacrene B & 1558 & 1559 & - & - & 16.3 \\
\hline Spathulenol & 1574 & 1577 & - & - & 3.3 \\
\hline Caryophyllene oxide & 1580 & 1582 & - & - & 2.1 \\
\hline Globulol & 1588 & 1590 & - & - & 1.6 \\
\hline Monoterpene hydrocarbons & & & 57.6 & 61.3 & 32.6 \\
\hline Oxygenated monoterpenes & & & 24.2 & 24.9 & 0.1 \\
\hline Sesquiterpene hydrocarbons & & & 11.2 & 4.0 & 53.2 \\
\hline Oxygenated sesquiterpenes & & & - & - & 7.0 \\
\hline Other & & & - & 0.7 & - \\
\hline Total & & & 93.0 & 90.9 & 92.9 \\
\hline
\end{tabular}

$\mathrm{RI}_{\mathrm{C}}$ : calculated retention time (on Rxi-5ms column); $\mathrm{RI}_{\mathrm{L}}$ : literature retention time (Adams) ${ }^{18}$ EpNRP-I and EpNRP-II: Eugenia punicifolia specimens from Parque Nacional das Nascentes do Rio Parnaíba; EpCM: Eugenia punicifolia specimens from Parque Nacional da Chapada das Mesas. Bold: primary constituents (above 5\%).

present in the EpNRP-I oil sample as its principal constituent (49.8\%) and present in the EpCM oil sample at low concentrations (5.2\%), displayed significant antiproliferative activity in some tumor cells, as previously reported. ${ }^{3}$ Based on this information and the significant $\alpha$-pinene content in E. punicifolia oils, complementary 


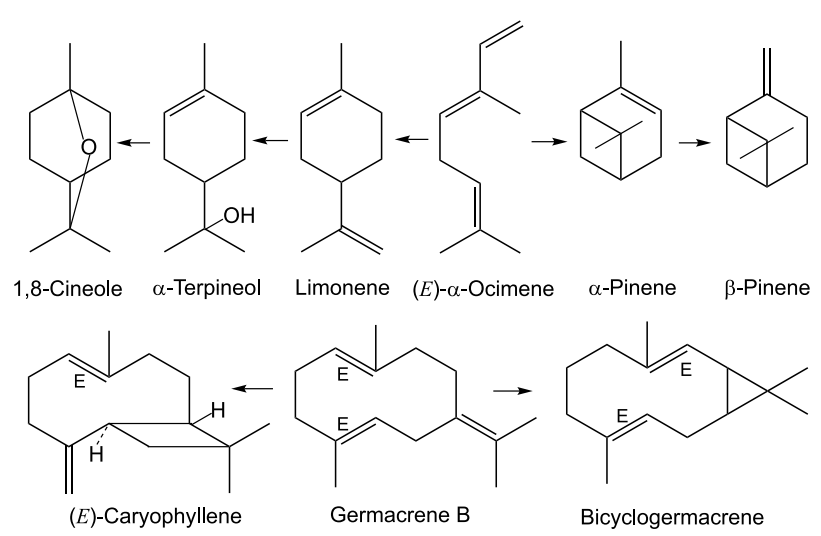

Figure 1. Principal monoterpenes and sesquiterpenes of E. punicifolia essential oil and their probable interconversions involving cyclization, isomerization, and hydroxylation biosynthetic reactions.

antiproliferative bioassays for the EpNRP-I and EpCM oil samples were carried out, including a third sample consisting of a mixture of EpCM oil and a commercial $\alpha$-pinene standard (99\%), in order to represent a similar percentage value to that of $\alpha$-pinene in the EpNRP-I oil sample. The third sample doped with the $\alpha$-pinene standard was named EpCM-d. Additionally, the $\alpha$-pinene standard was also separately subjected to bioassays to verify if it was directly responsible for antiproliferative activity.

The antiproliferative activities of the samples were plotted on graphs representing cell growth percentages according to sample concentration. When the growth parameter remained at zero or close to zero in the graphs, a cytostatic sample, where no cell development occurs, was characterized. On the other hand, a cytocidal sample displays negative cell growth. The growth inhibition $\left(\mathrm{GI}_{50}\right)$ results of the E. punicifolia EpNRP-I, EpCM, and EpCM-d oil samples, as well as for the $\alpha$-pinene standard and doxorubicin hydrochloride used as the positive control, are displayed in Figures 3 and 4.

EpNRP-I oil sample showed the lowest $\mathrm{GI}_{50}$ values for all tumor cell lines evaluated (Table 2), with glioblastoma
(U-251, $\mathrm{GI}_{50} 2.13 \mu \mathrm{g} \mathrm{m}^{-1}$ ) and breast adenocarcinoma (MCF-7, $\mathrm{GI}_{50} 6.72 \mu \mathrm{g} \mathrm{mL}^{-1}$ ) cell lines being the most sensitive to the treatment, with SI greater than 2.0 (Table 3). According to the National Cancer Institute (NCI), significant SI values are considered to be greater than or equal to 2.0. ${ }^{33}$ Doxorubicin presents SI values greater than 2.0 only for MCF-7 tumor cells. In addition, EpNRP-I showed cytotoxic effects for the non-tumoral keratinocytes line $(\mathrm{HaCaT})$, however, its effect was 43 times smaller when compared to the positive control of the assay, the chemotherapy drug doxorubicin hydrochloride (Table 2).

Although conventional chemotherapy has been successful to some extent, the main drawbacks of chemotherapy are its poor bioavailability, high-dose requirements and adverse side effects, proving the need and importance of researching new molecules with more effective anticancer activity and with no or minimal side effects.

Considering the low $\mathrm{GI}_{50}$ value for MCF-7, the $\mathrm{SI}=2.0$, together with the fact that this tumor type is the one that most affects Brazilian women and the existing treatments confer so many adverse effects to patients, this line was selected to continue the investigation of the antiproliferative activity of EpNRP-I. Although the focus of the study was the investigation of the antiproliferative activity of essential oil in breast tumor lineage, the result obtained for the glioblastoma lineage is quite interesting. Due to the presence of the blood-brain barrier, the implementation of new approaches for the treatment of glioblastoma is much more difficult than in the case of other tumors. The selectivity of this barrier reduces the bioavailability of hydrophilic drugs in the central nervous system. The volatile constituents of essential oils are believed to easily cross the blood-brain barrier due to their small molecular size and lipophilic nature. ${ }^{34}$ Therefore, we encourage the continuity of studies with the U-251 cell line.

The EpCM oil sample doped with the $\alpha$-pinene standard and the $\alpha$-pinene standard sample alone did

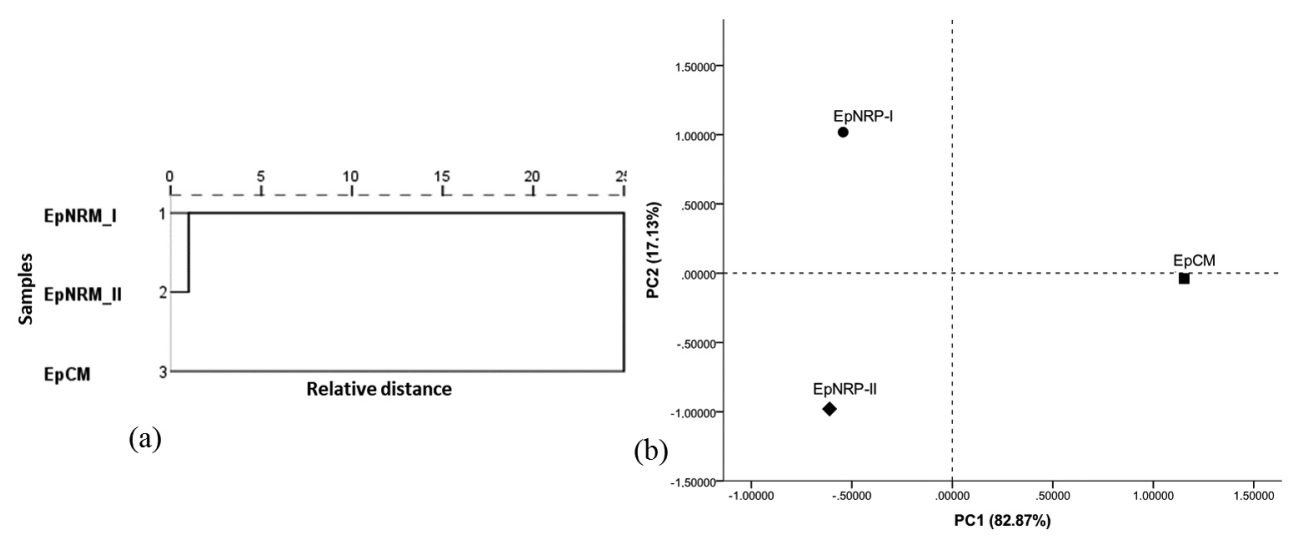

Figure 2. (a) HCA dendrogram obtained by Ward's algorithm and squared Euclidean distance measure criterion, and (b) principal components analysis (PCA) of the Eugenia punicifolia oils, based on their main constituents. 



Figure 3. Cell growth percentage after $48 \mathrm{~h}$ treatment with (a) EpNRP-I; (b) EpCM; and (c) EpCM-d EO samples obtained from E. punicifolia.
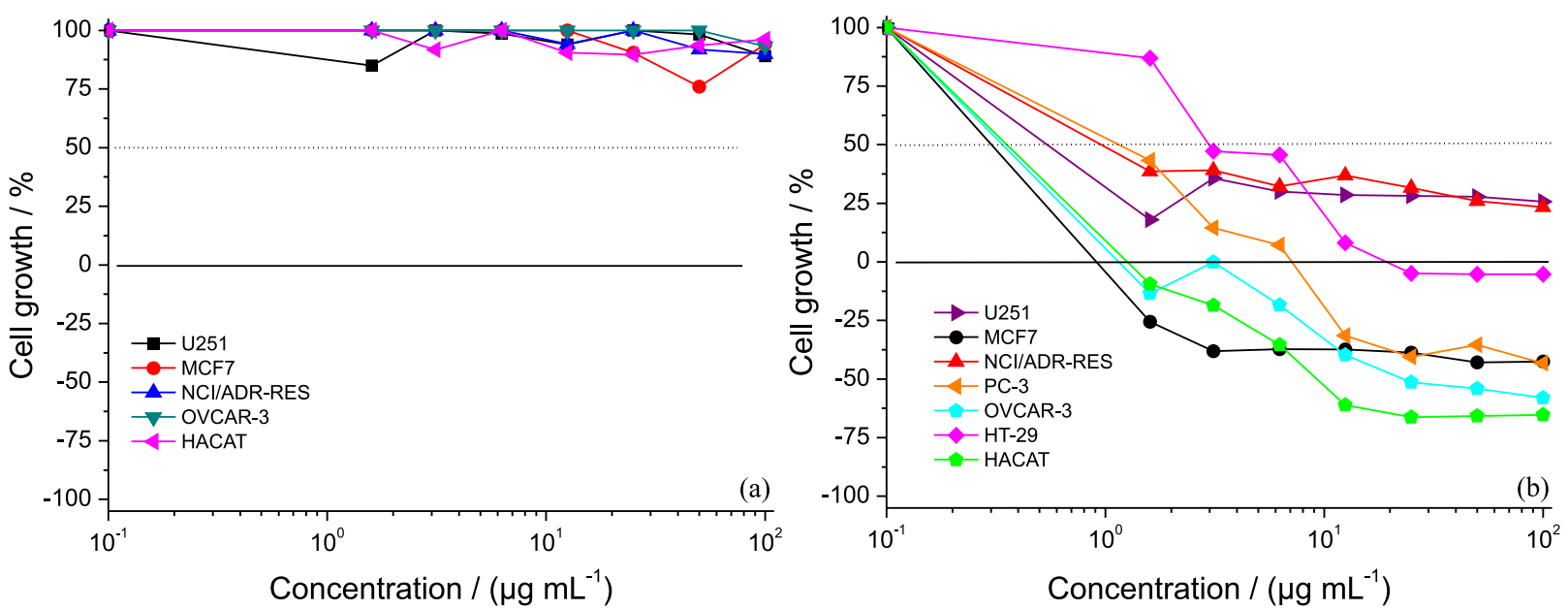

Figure 4. Cell growth percentage after $48 \mathrm{~h}$ treatment with (a) $\alpha$-pinene standard and (b) the doxorubicin hydrochloride positive control.

not present low $\mathrm{GI}_{50}$, in contrast to that observed for EpNRP-I. Although $\alpha$-pinene has been reported ${ }^{3,35}$ as an important monoterpenoid with activity against various human cancer cell lines through apoptosis stimulation by mitochondrial function disruption, reactive oxygen species (ROS) formation, caspase-3 activation, heterochromatin aggregation, DNA disintegration, and cell surface phosphatidylserine exposure, our results suggest that the active compound responsible for the antiproliferative action may not be $\alpha$-pinene, or at least not only $\alpha$-pinene. Therefore, the hypothesis of a synergistic effect, resulting from diverse oil constituent action, is much more likely. ${ }^{36}$ 
Table 2. Displays the $\mathrm{GI}_{50}$ values of cell growth for the analyzed oil samples and the standards $\alpha$-pinene and doxorubicin, obtained by non-linear regression

\begin{tabular}{|c|c|c|c|c|c|c|c|}
\hline \multirow{2}{*}{ Sample } & \multicolumn{7}{|c|}{$\mathrm{GI}_{50} /\left(\mu \mathrm{g} \mathrm{mL}^{-1}\right)$} \\
\hline & $\mathrm{U}-251$ & MCF-7 & NCI/ADR-RES & PC-3 & OVCAR-3 & HT-29 & $\mathrm{HaCaT}$ \\
\hline EpNRP-I & 2.13 & 6.72 & 13.23 & 27.61 & 8.51 & 33.09 & 13.35 \\
\hline ЕрСM & $>100$ & 97.18 & $>100$ & ne & $>100$ & ne & $>100$ \\
\hline EpCM-d & $>100$ & $>100$ & $>100$ & ne & $>100$ & ne & $>100$ \\
\hline$\alpha$-Pinene & $>100$ & $>100$ & $>100$ & ne & $>100$ & ne & $>100$ \\
\hline Doxorubicin & 5.58 & 0.12 & 1.72 & 1.46 & 0.39 & 3.90 & 0.31 \\
\hline
\end{tabular}

$\mathrm{GI}_{50}$ : concentration required to inhibit 50\% cell growth; U-251: glioblastoma; MCF-7: breast adenocarcinoma; NCI-ADR/RES: multidrug-resistant ovarian adenocarcinoma; PC-3: prostate adenocarcinoma; OVCAR-3: ovarian adenocarcinoma; HT-29: colorectal adenocarcinoma; HaCaT: non-tumor keratinocyte; EpNRP-I: Eugenia punicifolia specimens from Parque Nacional das Nascentes do Rio Parnaíba; EpCM: Eugenia punicifolia specimens from Parque Nacional da Chapada das Mesas; EpCM-d: EpCM doped with the $\alpha$-pinene standard; ne: not evaluated. Treatment performed in $48 \mathrm{~h}$.

Table 3. Selectivity indexes (SI) for EpNRP-I and doxorubicin ${ }^{\mathrm{a}}$

\begin{tabular}{lcccccc}
\hline \multirow{2}{*}{ Sample } & \multicolumn{9}{c}{ SI } \\
\cline { 2 - 7 } & U-251 & MCF-7 & NCI/ADR-RES & PC-3 & OVCAR-3 & HT-29 \\
\hline EpNRP-I & 6.3 & 2.0 & 1.0 & 0.5 & 1.6 & 0.4 \\
Doxorubicin & 0.1 & 2.6 & 0.2 & 0.2 & 0.8 & 0.1 \\
\hline
\end{tabular}

${ }^{a}$ After $48 \mathrm{~h}$ treatment. U-251: glioblastoma; MCF-7: breast adenocarcinoma; NCI/ADR-RES: multidrug-resistant ovarian adenocarcinoma; PC-3: prostate adenocarcinoma; OVCAR-3: ovarian adenocarcinoma; HT-29: colorectal adenocarcinoma; EpNRP-I: Eugenia punicifolia specimens from Parque Nacional das Nascentes do Rio Parnaíba.

Another important result obtained in this assay comprised $\mathrm{GI}_{50}$ values for HaCaT (keratinocytes). EpNRP-I was 43-fold less toxic to this non-tumoral cell line compared to doxorubicin, a chemotherapeutic drug widely applied in the medical clinic context. This result is very interesting, as it may predict a selective effect for the assessed tumoral cell line. However, despite advances in chemotherapy treatments, many patients do not undergo this type of intervention, mainly due to the effects caused by non-tumor cells, proving the need and importance of researching new molecules with more effective anticancer activity and minor effects. The antiproliferative activity of the extract was further confirmed by a soft agar clonogenic assay. This assay measures the potential of cells to expand into colonies, which reflects the ability of cells to proliferate. ${ }^{37}$ As presented in Figure 5, there was a reduction of $63 \%$ in the number of cell colonies after treatment with
EpNRP-I. This result corroborates the findings obtained through the MTT assay and highlights EpNRP-I potential antiproliferative activity.

\section{Cell cycle analysis}

It was possible to observe an increase from 9.3 to $20.0 \%$ in the number of MCF-7 (breast adenocarcinoma) cells in the second phase of interphase (S phase) when the EpNRP-I oil sample of E. punicifolia was applied. Also, the cells treated with etoposide, the positive control, increased from 9.3 to $26.7 \%$, considering the same treatment time ${ }^{38}$ Consequently, in the analysis of the EpNRP-I oil sample, there was a reduction from 87.5 to $78.0 \%$ in the number of cells in the first phase of the interphase (G1 interval), and in the positive control, this reduction was from 87.5 to $71.8 \%$. The results were compared to negative control DMSO (see Figure 6).
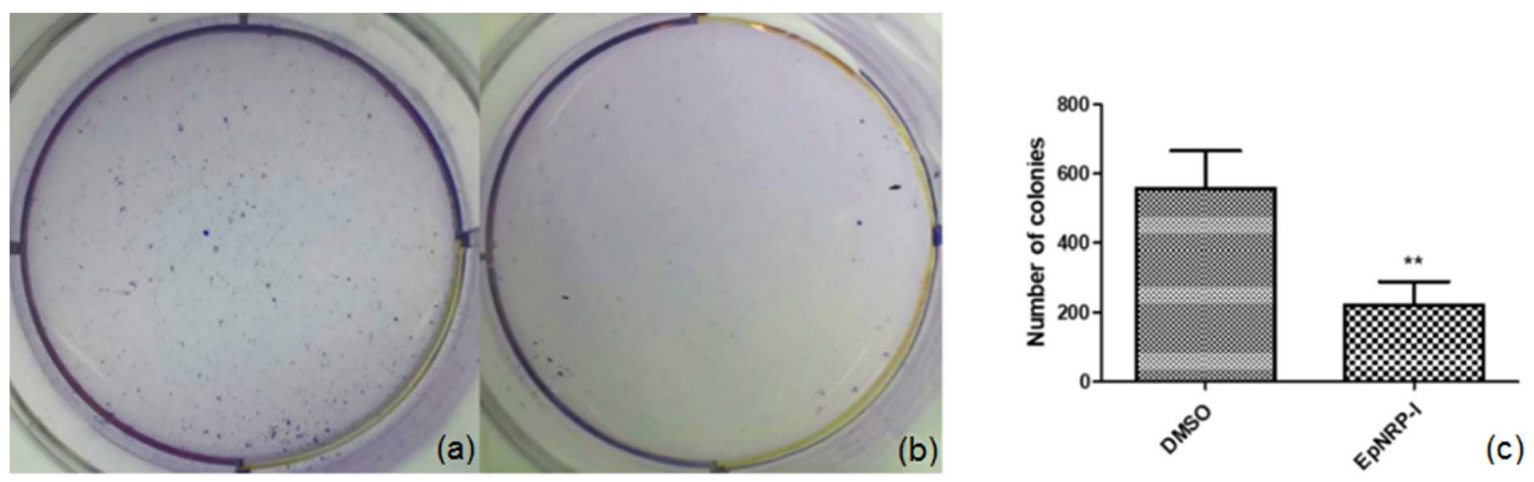

Figure 5. Soft agar clonogenic assay presenting the effect of EpNRP-I on MCF-7 colony formation. Treatment: (a) DMSO control and (b) $7 \mu \mathrm{g} \mathrm{mL}^{-1}$ EpNRP-I. (c) Number of MCF-7 colonies formed. $* * p<0.01$ ( $t$ test). 


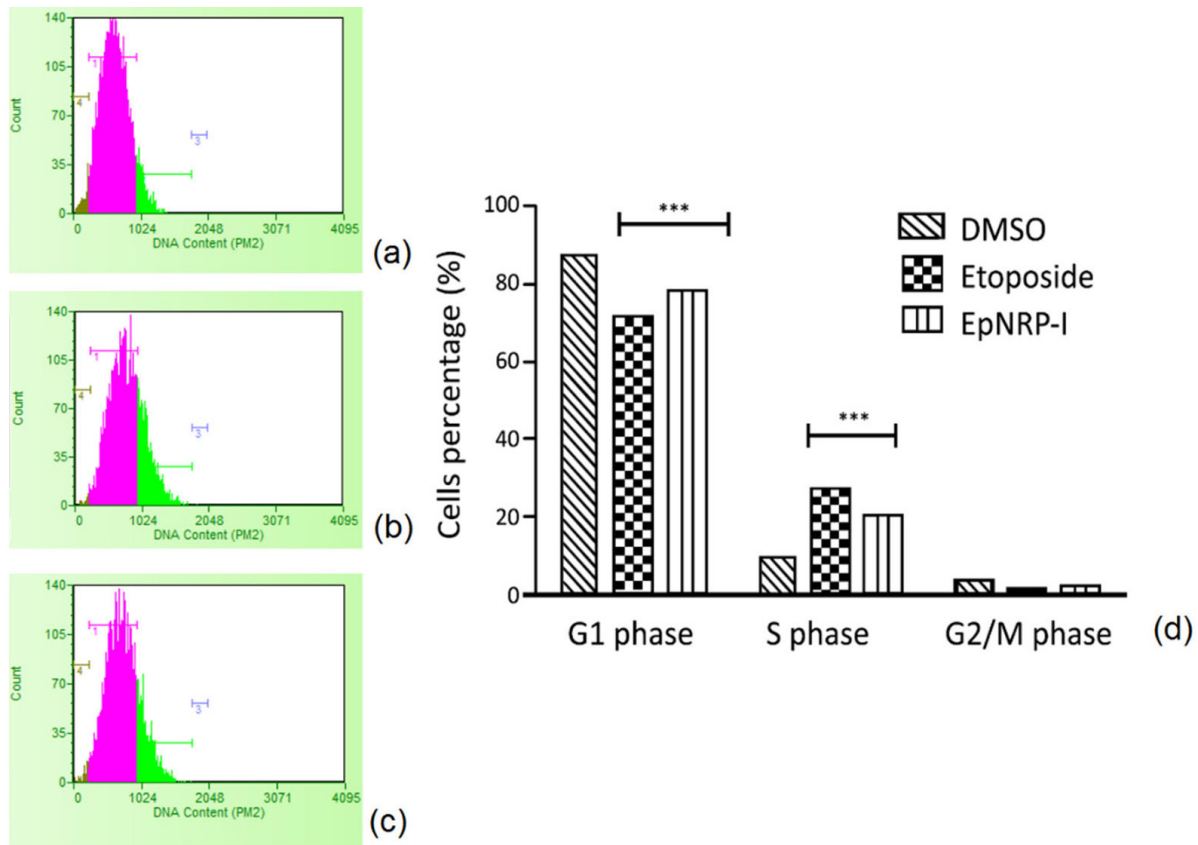

Figure 6. Representative flow cytometry histograms of cell cycle analysis (G1 phase: pink color; S phase: green color; G2/M phase: purple color) of (a) DMSO; (b) etoposide control $\left(5.89 \mu \mathrm{g} \mathrm{mL}^{-1}\right)$ and (c) EpNRP-I sample $(7 \mu \mathrm{g} \mathrm{mL}-1)$. (d) MCF-7 cells percentage after $24 \mathrm{~h}$ of treatment. $* * * p<0.01$. One-way ANOVA followed by Bonferroni's post-hoc.

\section{Conclusions}

The findings reported herein indicate differences in the chemical composition of the EO samples obtained from aerial Eugenia punicifolia parts from two different locations. In addition, an expressive antiproliferative potential was noted for the EpNRP-I oil sample. However, no relationship between this activity and a single constituent was observed. A flow cytometry analysis indicates that the sample induces cell cycle arrest in the genetic material duplication phase in cells belonging to MCF-7 cell line. The results of the present study showed the potential chemical composition and the technological application of Eugenia punicifolia essential oil, in favor of Brazilian society.

\section{Acknowledgments}

This work was supported by grants from Coordenação de Aperfeiçoamento de Pessoal de Nível Superior (grant No. 88887.472618/2019-00-PROCAD-AM (C. Q. R.)) and Fundação de Amparo à Pesquisa do Estado de São Paulo (FAPESP, grant No. 2018/19436-7 (J. V. S. M) and 2016/06137-6 (G. B. L.)).

\section{Author Contributions}

Yan M.L.Fernandes was responsible for the methodology, validation, investigation, formal analysis, writing original draft; Julia V. S. Matos for the methodology, validation, investigation, formal analysis; Carolina A. Lima for the methodology, validation, investigation, formal analysis; Angela M. Tardini for the methodology, investigation; Flavio A. P. Viera for the methodology, validation; Jose G. S. Maia for the writing review and editing; Odair S. Monteiro for the methodology, investigation; Giovanna B. Longato for the conceptualization, investigation, resources, writing review and editing, project administration, funding acquisition; Cláudia Q. Rocha for the conceptualization, investigation, resources, writing review and editing, project administration, funding acquisition.

\section{References}

1. da Silva, J.; Andrade, E.; Barreto, L.; da Silva, N.; Ribeiro, A.; Montenegro, R.; Maia, J.; Medicines 2017, 4, 51.

2. Figueiredo, P. L. B.; Pinto, L. C.; da Costa, J. S.; da Silva, A. R. C.; Mourão, R. H. V.; Montenegro, R. C.; da Silva, J. K. R.; Maia, J. G. S.; J. Ethnopharmacol. 2019, 232, 30.

3. Sobral, M. V.; Xavier, A. L.; Lima, T. C.; de Sousa, D. P.; Sci. World J. 2014, 1, 35.

4. Padovan, A.; Keszei, A.; Külheim, C.; Foley, W. J.; Phytochem. Rev. 2014, 13, 695.

5. Maia, O. G. S.; Andrade, L. H. A.; Quim. Nova 2009, 32, 595.

6. Machado, R. B.; Ramos Neto, M. B.; Pereira, P. G. P.; Caldas, E. F.; Gonçalves, D. A.; Santos, N. S.; Tabor, K.; Steininger M.; Estimativas de perda da Área do Cerrado Brasileiro; Conservação Internacional: Brasília, DF, 2004, avaliable at http://jbb.ibict.br//handle/1/357, accessed in March 2021. 
7. Van Der Merwe, M. M.; Van Wyk, A. E.; Botha, A. M.; Plant Syst. Evol. 2005, 251, 21.

8. Ogunwande, I.; Olawore, N.; Ekundayo, O.; Walker, T.; Schmidt, J.; Setzer, W.; Int. J. Aromather. 2005, 15, 147.

9. Lee, Y.-S.; Kim, J.; Shin, S.-C.; Lee, S.-G.; Park, I.-K.; Flavour Fragrance J. 2008, 1, 23.

10. Gonzalez, M. S.; Lima, B. G.; Oliveira, A. F. R.; Nunes, D. D.; Fernandes, C. P.; Santos, M. G.; Tietbohl, L. A. C.; Mello, C. B.; Rocha, L.; Feder, D.; Rev. Bras. Farmacogn. 2014, 24, 413.

11. Ambrož, M.; Boušová, I.; Skarka, A.; Hanušová, V.; Králová, V.; Matoušková, P.; Szotáková, B.; Skálová, L.; Molecules 2015, $20,15343$.

12. da Costa, J. S.; da Cruz, E. N. S.; Setzer, W. N.; da Silva, J. K. R.; Maia, J. G. S.; Figueiredo, P. L. B.; Biomolecules 2020, 10, 1155 .

13. Aranha, E. S. P.; de Azevedo, S. G.; dos Reis, G. G.; Lima, E. S.; Machado, M. B.; de Vasconcellos, M. C.; Ind. Crops Prod. 2019, 141, 111736.

14. Mondello, L.; Flavors and Fragrances of Natural and Synthetic Compounds: Mass Spectral Database, $2^{\text {nd }}$ ed.; John Wiley \& Sons Inc.: Hoboken, NJ, USA, 2011.

15. Sobral, M.; Proença, C.; Souza, M.; Mazine, F.; Lucas, E.; Myrtaceae in Lista de Espécies da Flora do Brasil; Jardim Botânico do Rio de Janeiro: Rio de Janeiro, 2015, available at http://floradobrasil.jbrj.gov.br/jabot/floradobrasil/FB10515, accessed in March 2021.

16. de Souza, A. M.; de Oliveira, C. F.; de Oliveira, V. B.; Betim, F. C. M.; Miguel, O. G.; Miguel, M. D.; Planta Med. 2018, 84, 1232.

17. National Institute of Standards and Technology (NIST); Mass Spectral Library (NIST/EPA/NIH, v.2.0d); The NIST Mass Spectrometry Data Center: Gaithersburg, USA, 2005.

18. Adams, R. P.; Identification of Essential Oil Components by Gas Chromatography/Mass Spectrometry, $4^{\text {th }}$ ed.; Allured Publishing: Carol Stream, 2007.

19. Van Den Dool, H.; Kratz, P. D.; J. Chromatogr. 1963, 11, 463.

20. Mosmann, T.; J. Immunol. Methods 1983, 65, 55.

21. Franco, Y. E. M.; de Lima, C. A.; Rosa, M. N.; Silva, V. A. O.; Reis, R. M.; Priolli, D. G.; Carvalho, P. O.; Nascimento, J. R.; Longato, G. B.; Nat. Prod. Res. 2020, DOI 10.1080/14786419.2020.1727470.

22. OriginLab; Origin, 8.0; OriginLab, USA, 2008.
23. Rasband, W.; ImageJ, 2.0.0-rc-3; National Institutes of Health, USA, 2014.

24. Franco, Y. E. M.; Okubo, M. Y.; Torre, A. D.; Paiva, P. P.; Rosa, M. N.; Silva, V. A. O.; Reis, R. M.; Ruiz, A. L. T. G.; Imamura, P. M.; de Carvalho, J. E.; Longato, G. B.; Molecules 2019, 24, 449.

25. Luminex Corporation; Guava Cell Cycle, 3.4; Luminex Corporation, USA, 2010.

26. GraphPad Software; GraphPad Prism 5; GraphPad Software, USA, 2007.

27. SPSS Statistics, version 22.0; IBM, Chicago, USA, 2013.

28. Oliveira, R. N.; Dias, I. J. M.; Câmara, C. A. G.; Rev. Bras. Farmacogn. 2005, 15, 39.

29. Gobbo-Neto, L.; Lopes, N. P.; Quim. Nova 2007, 30, 374.

30. Dewick, P. M.; Nat. Prod. Rep. 2002, 19, 181.

31. Maia, J. G. S.; Zoghbi, M. G. B.; Luz, A. I. R.; J. Essent. Oil Res. 1997, 9, 8.

32. Ramos, M. F. S.; Monteiro, S. S.; da Silva, V. P.; Nakamura, M. J.; Siani, A. C.; J. Essent. Oil Res. 2010, 22, 109.

33. Suffness, M.; Pezzuto, J. M. In Methods in Plant Biochemistry: Assays for Bioactivity, vol. 6; Hostettmann, K., ed.; Academic Press: London, UK, 1990, p. 71-133.

34. Ayaz, M.; Junaid, M.; Ullah, F.; Sadiq, A.; Khan, M. A.; Ahmad, W.; Shah, M. R.; Imran, M.; Ahmad, S.; Lipids Health Dis. 2015, 14, 141.

35. Salehi, B.; Upadhyay, S.; Orhan, I. E.; Jugran, A. K.; Jayaweera, S. L. D.; Dias, D. A.; Sharopov, F.; Taheri, Y.; Martins, N.; Baghalpour, N.; Cho, W. C.; Sharifi-Rad, J.; Biomolecules 2019, 9, 738.

36. Matsuo, A. L.; Figueiredo, C. R.; Arruda, D. C.; Pereira, F. V.; Scutti, J. A. B.; Massaoka, M. H.; Travassos, L. R.; Sartorelli, P.; Lago, J. H. G.; Biochem. Biophys. Res. Commun. 2011, 411, 449.

37. Santos, A. F.; Schiefer, E. M.; Atherino, M. C.; Atherino, J. C.; Negri, L. H.; Weffort-Santos, A. M.; Crisma, A. R.; de Souza, W. M.; Felipe, K. B.; J. Pharmacol. Toxicol. Methods 2020, 106, 106911.

38. Weng, J. R.; Bai, L. Y.; Lin, W. Y.; Chiu, C. F.; Chen, Y. C.; Chao, S. W.; Feng, C. H.; Molecules 2017, 22, 472.

Submitted: October 11, 2020 Published online: March 15, 2021 